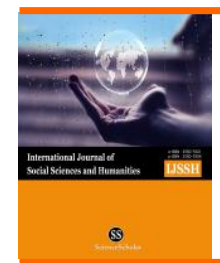

International Journal of Social Sciences and Humanities

Available online at http://sciencescholar.us/journal/index.php/ijssh

Vol. 1 No. 3, December 2017, pages: 28 38

e-ISSN: 2550-7001, p-ISSN: 2550-701X

http://dx.doi.org/10.21744/ijssh.v1i3.50

\title{
Criminal Law Policy on Land Functions Impacting Climate Change in Indonesian National Law Perspective
}

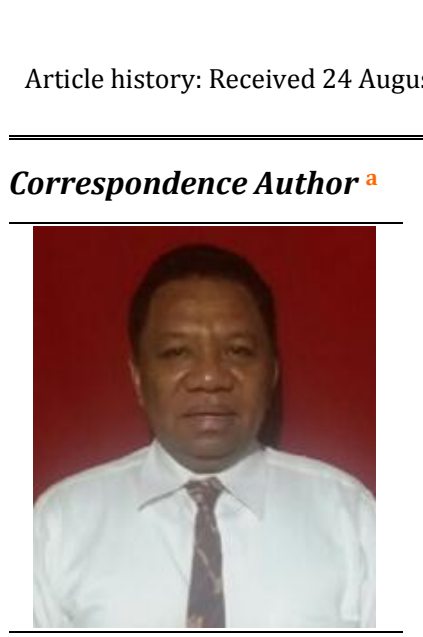

Keywords

Climate change;

Criminal law policy;

Land alteration;

Functions;

National perspective;

\section{Simon Nahak ;} Available online 1 December 2017

\section{Abstract}

The philosophy of functional transfer of land from wetlands, paddy fields, watersheds, protected forests, coastal and lake reclamation into residential areas in a national perspective, is one of the causes of climate change today. Initially, these places provide a cool, fresh, and clean air for humans being and the environment, but with the transition of the functions of these lands, an unexpected impact arises from the emergence of pollution, climate change that led to the occurrence of global warming. Philosophically, the transition of land functions is prohibited because it affects the human life. Sociologically, human actions that are deliberately destructive to the environment by transforming agrarian lands into residential areas, factories, hotels and large malls so that previously productive land, turning into polluted lands, must be illegal due to land misuse as opposed to the public interest. Thus, juridical, a regulation that will be highlighted from the criminal law aspects both in the case of criminal acts, criminal liability, and the formulation of the punishment system against any person or legal body proven to commit criminal acts in the case of abuse of land functions, resulting in the change Climate that threatens the safety of mankind. This paper uses normative juridical approach method with some analysis in the form of legal theories related to the writing of this journal.

e-ISSN : 2550-7001, p-ISSN : 2550-701X@ Copyright 2017. The Author. SS Journals Published by Universidad Técnica de Manabí.

This is an open-access article under the CC BY-SA 4.0 license

(https://creativecommons.org/licenses/by-sa/4.0/) All rights reserved.

a Head of Master of Law Department Program, Warmadewa University, Denpasar, Bali-Indonesia (simonnahaklawoffice@yahoo.com) 


\section{Contents}

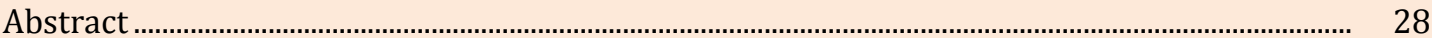

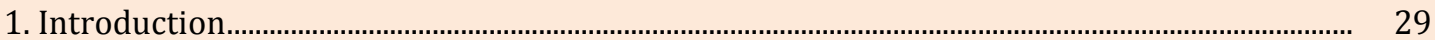

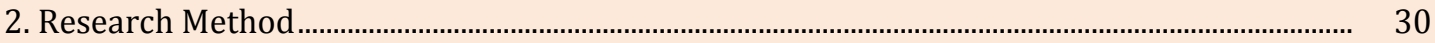

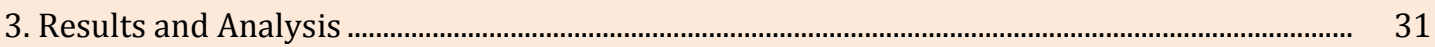

3.1Qualification of types of acts, errors and punishment systems for land conversion that impact climate change in a national perspective ............................................................................. 31

3.2 Criminal sanctions regulation of land conversion that impact climate change in national

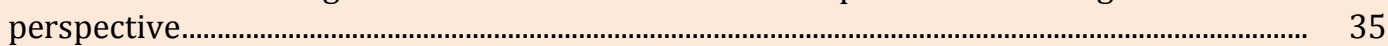

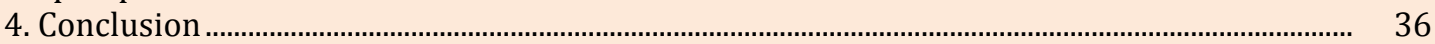

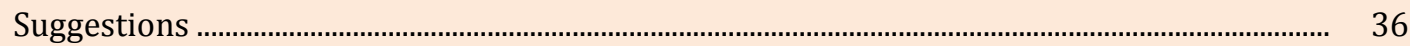

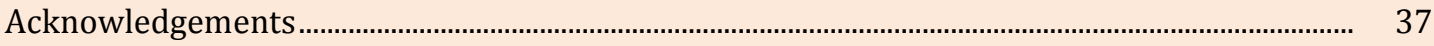

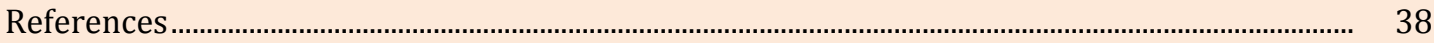

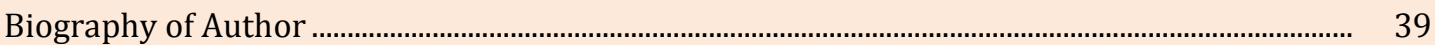

\section{Introduction}

Today, climate change caused by global warming is at an alarming phase, threatening the existence of the earth and everything in it. Climate change has touched a multidimensional condition with high complexity. James C. Wood in the paper Deni Bram (2016), states that, global warming is caused by the accumulation of greenhouse gases, in the atmosphere layer derived from human actions. Human action referred to is, various activities undertaken by humans, such as energy production processes, industrial activities, plantations and forestry that can produce potential impacts on worsening climatic conditions in the future.

Climate change, too, can be caused by the transfer of land functions that humans do today. Protected forest lands converted into housing, converted rice fields into store houses, beach and lake reclamation for hotel development purposes, all contributing to climate change leading to global warming.

Deni Bram writes that "some of the impacts in the same time dimension now indicate that developing countries have far greater vulnerabilities than more advanced countries" 1 . Furthermore, Deni Bram writes that "currently developing 2 (two) models of commitment in climate change mitigation measures are commitments that rely on top down models and commitments that rely on botton up models. The top down model carried out in the model of commitment formation in the Kyoto Protocol has failed from the perspective of fairness and effectiveness. This inevitably leads to a lack of clarity as to whether the emission reduction commitments in the Kyoto Protocol are based on the goals set forth in the UNFCCC regime, which is to achieve stable greenhouse gas conservation at a safe level. This failure is exacerbated by the failure of one of the largest emitters, namely the United States to ratify the Kyoto Protocol, as well as the failure of some countries to achieve the emission reduction targets set by the Kyoto Protocol ${ }^{2}$.

Based on the description, it is clear that in the process of establishing legal arrangements to anticipate the violations occurring as a result of the transfer of land functions affecting climate change in Indonesia, it is necessary to have Civil Law, State Administration and Criminal Law, against the perpetrators of land transfers Individually or legal entity. If it has been proven that intentionally conducting unlawful development activities affecting climate change should be subject to strict sanctions and in this case a criminal sanction is necessary.

Galvin A. Toala Arcentalis, Reinaldo Guillen Gordin, Antonia Vazquez Perez, Alfredo Zambrano Rodfiquez wrote that "it is known that approximentely $15 \%$ of the energy consumedin Ecuador is used for the operation of climate conditioning equipment and, on the other hand, most of the Existing technology operates on the basis of the use of refrigerant gases are invasive to the azone layer...." "3.

Nahak, S. (2017). Criminal law policy on land functions impacting climate change in Indonesian national law perspective. International Journal of Social Sciences and Humanities, 1(3), 28-39. https://doi.org/10.29332/ijssh.v1n3.50 
Climate change greatly affects the lives of mankind so that this paper examines it in terms of formulation The establishment of norms or substance of criminal law that is still blank legal (blanc norm of law), especially in terms of qualifications of types of criminal acts, errors and criminal responsibility and penal system. This formulation is necessary to regulate the legal aspects of climate change as a problem that is addressed to safeguard the earth, water and air which are truly beneficial to the life of all humanity in general and Indonesian people in particular.

Based on the above background then formulated legal issues (legal issue) as follows:

1. What qualifies types of acts, wrongs and punishment systems for land conversion that negatively impact climate change in a national perspective?

2. How is the regulation of criminal law sanction against land conversion that negatively impacts climate change in national perspective?

\section{Research Method}

The writing method used in this journal is using the Juridical-Normative method of writing. Peter Mahmud Marzuki writes that the variety of research using the normative approach is: statute approach, case approach, historical approach, comparative approach, conceptual approach ${ }^{4}$. While J. Ibrahim has the same opinion with Peter Mahmud Marzuki but adds again the analytical approach (analytical approach) and philosophical approach (philosophical approach). The approach used is the approach of legislation, conceptual approach, historical approach, analytical approach and philosophical approach ${ }^{5}$.

Valerine J.L. Kriekhoff, a retired Supreme Court Justice of the Republic of Indonesia wrote that: The Application of Normative Law Research in Criminal Law applies normative legal research in criminal law studies related to:

1. Learning objectives in each strata of legal education

2. Coverage of legal research, within this scope of criminal law research includes:

a. Legal concepts such as the concept of "right of self determination" or the concept of "Whistle Blower" and research on the principle of law, for example the principle of "presumption of innocence"

b. Historical research which may include legal history (d.h.i criminal law), or history of legislation;

c. Case studies, by tracing the 'decidendi ratios' in decisions or analyzing the existence of 'heteronomy' or 'autonomy'6 in a decision on the basis of the "Legal Discourse Theory" or Theory of Legal Argumentation?.

d. Comparative studies that may include comparison of law enforcement agencies in some countries (such as the KPK) comparisons of laws (such as the Juvenile Justice Act, Money Laundering);

e. Analytical research, for example, analyzes the Criminal Concept of FMD in environmental crime cases, or the concept of 'discretion' in corruption committed by state officials;

f. Theoretical approaches, such as research on the theory of punishment (or which can be combined with philosophical and comparative research-as in the civil law and common law systems ${ }^{8}$.

The description confirms that the method used in the writing of this journal is the juridicalnormative method of writing as described by Peter Mahmud Marzuki, Johny Ibrahim and Valerine J.L. Kriekhoff above. 
3. Results and Analysis

3.1Qualification of types of acts, errors and punishment systems for land conversion that impact climate change in a national perspective

a. Types of Criminal Acts in the field of climate change in the National perspective

Article 4 of the Indonesian Criminal Code provides that "every person, whether an Indonesian citizen, or a foreign national who commits a crime as referred to in this article, even outside of Indonesia may be subject to Indonesian criminal provisions".

The description of qualification / type of criminal act that distinguishes the violation in the form of accidental deeds and crime in the form of deliberate acts, in relation to the offense, the culpa and dolus shall be regulated in Chapter, Article of Criminal Provisions regulating specifically the criminal acts of climate change which endanger the life of mankind.

Actually the action in the form of a series of criminal acts of environmental pollution and spatial abuse has been regulated in the Environmental and Spatial Planning Act, but the negative impacts of climate change that harm human beings, not yet regulated by law. In fact, there is a lot of misuse of spatial planning and environmental pollution, such as the use of laserdiscs to break the clouds, excessive use of greenhouses, the transition of land functions from rice fields to homes or shop houses, from protected forests to hotels or factories, to marine reclamation And lakes for industrial development or hotels, as well as other deeds that are systemized on behalf of development.

Based on Article 1 paragraph (19) of Law of the Republic of Indonesia Number 32 Year 2003 on Environmental Protection and Management determines that:

"Climate change is the change of climate which is directly or indirectly caused by human activity causing changes in atmospheric composition globally and in addition, also changes in natural climate variability observed at comparable time periods".

Spatial Criminal Act as stipulated in Indonesian Law No. 26 Year 2007 on Spatial Planning (LN Year 2007 No. 84, TLN No. 4725 in the form of non-compliance with the land use plan, not in accordance with the permit of spatial use from the authorized official, then resulting in the death of everyone.

The theory relating to the authority to qualify such crimes and offenses is affirmed in the theory of State Power, so that the authority to form the Law lies in the executive and legislative powers while the authority to judge lies in the judicial power. These three powers refer to the theory of separation of powers based on the teachings of the Tries Politics of Montesquieu (1689-1755), namely the legislative, executive and judicial authorities, which, in practice, Not fully adopted in the country of Indonesia therefore need to be equipped with cheks and balances with the principle of cheking power with power so that it becomes intact as the State fundamentals.

The study and legal analysis of the Authority Theory also by using Pure Theory of Law theory by Hans Kelsen who writes that:

"Regarding Positive and Negative Regulations: Commanding, Authorizing, Permiting and the Structural Structure of the Legal Order, which describes the positive law that must be separated by moral, economic, social and cultural, and Positive and Negative Rules: Order / The hierarchical structure of the legal order ${ }^{9}$.

Paul Scholten rejected Hans Kelsen's view on the grounds that:

"Legal judgments are nothing but the logical processing of positive materials, the laws, the verdicts, and so on. According to Paul Scholten these positive materials are determined historically and socially. The enactment of a law is a historical event that is the result of a set of socially determined facts. Therefore the purity of jurisprudence always contains something impure from its material. According to Paul Scholten if it is not done then the science of law will become a creature without blood "10.

Referring to Paul Scholten's opinion, setting the qualification of violations and crimes against the Criminal Actors in the field of climate change in Indonesia, requires the formulation of criminal sanctions with due regard to legal materials in the form of laws, verdicts and legal

Nahak, S. (2017). Criminal law policy on land functions impacting climate change in Indonesian national law perspective. International Journal of Social Sciences and Humanities, 1(3), 28-39. https://doi.org/10.29332/ijssh.v1n3.50 
theories of pure, Attention to the ability of the community, especially the perpetrators of criminal acts in the field of climate change in terms of economic, cultural and sociological aspects.

John Rawls emphasizes that justice is closely related to the distribution of rights and duties. The opinion proves that to formulate criminal sanction against perpetrators of criminal acts in the field of environment and structuring of City Territory should be considered the rights and obligations of the perpetrators, from the economic aspect that is about the economic ability of the perpetrators in their obligation to run the punishment.

Based on the description, Simon Nahak writes that:

"Against perpetrators / perpetrators of general or special crimes are expressed through 3 (three) dimensions to disclose their crimes: First, perpetrators: any person / legal entity that commits a series of offenses in the form of an act of doing or not doing something which by law The offense is punishable by criminal law, where the act is unlawful (Civil, Administration and Criminal) or is contrary to the law that lives in the society, either in the form of a structured / systemized action, by accident, Which occurs because of need (by need). Second, Proof: The determination of the defendant's faults based on evidence, whether by law or by law, the tools which are permitted to be used prove the arguments of a party before the court, for example: evidence Writing, testimony, presupposition, oath; Third, Victim: a person / group of people who suffer physical, mental, and / or economic losses caused by a crime (vide Article 1 paragraph (2) of RI Law No. 13 of 2006 on the Protection of witnesses and victims) ${ }^{11}$.

Criminal acts in the form of a series of criminal acts in the field of climate change, usually done in a structured / systematic and organized by each person / group of people together. An example of a crime of environmental crime may be a transitional crime of land use by a legal entity resulting in climate change that has a negative impact on humans by a giant company transacting nationally, having a large capital to dominate the global (International) economy.

\section{b. Crime and Criminal Accountability Against Criminal Aspects of Climate Change}

In Moeljatno's opinion, the notion of "accountability" in the criminal law is "whether in doing an act, a person has a fault"? The principle of accountability in terms of criminal law is that a person can not be punished if there is no mistake (geenstrafzonderschuld; actus non facitreum nisi mens sir rea) ${ }^{12}$.

Based on these descriptions, to measure whether a person is guilty and proven to be unlawful must be eligible as measured by the evil spirit of a person / legal body (mens rea), and the actual act of physical contact (actus reus), or Opzet which can be translated as deliberate commit crime. In the criminal law opzet is one element of the offense. The essence of opzet in the Criminal Code is not clear, therefore the solution is analyzed using the approach of two (2) theories as follows:

1) dewiltheorie, the theory of will, must occur; The intent is intended for an act prohibited / required by law;

2) de voorstellingtheorie; Theory of expectation, hope has not happened, that people only estimate / expect the realization of an action but the result of the action is not definitely realized, therefore the theory of expectations / expectations ${ }^{13}$.

Based on the theory then the party who can be held responsible is the legal subject (legal subject), as the carrier or the owner of rights and obligations in legal relations, where the legal subject can be a person or natuurlijkpersoon (menselijkpersoon) and not a person (rechtspersoon). Rechtspersoon is usually called a legal entity that is persona ficta or person created by law as persona. In a criminal offense in the land sector, as a party to which criminal responsibility is liable is a responsibility of every person and corporate legal entity in which there is a legal subject person and legal subject of legal entity.

The description of criminal liability can be explained as follows: 


\section{1) Individual responsibility}

The definition of the subject of crime includes two things, namely who committed the criminal acts (the perpetrators of criminal acts), and who can be accountable. This depends on the manner or system of accountability made by the legislator.

Individual responsibility is a very basic accountability which means, if a person commits a criminal offense in the field of land inherent in it. Responsibility of legal subject individual/legal entity in the field of Environment and Arrangement of City Area can be divided in several stages:

The first stage: on the process of investigation and investigation as a suspect to be made a Proceedings of examination (BAP).

Second Stage: The responsibility of legal subjects in the judicial process as defendants is always required to be present in every trial in the Court.

Third Stage: Accountability of a criminal law subject as a convicted person, after being convicted by a Judge then the Judge will hand the verdict (verdict).

According to traditional theory there are 2 (two) kinds of accountability are:

(1) Fault-based (based on fault) accountability;

(2) Absolute responsibility (absolute responsibility).

The latest legal techniques require a distinction between the case of a planned individual action and is intended to inflict certain effects on the act and other cases, when unplanned action of an individual that brings harmful consequences to the victim.

Based on the above description, the responsibility for environmental crime and City Area Arrangement is a liability based on fault or culpability.

\section{2) Liability of Legal Entity}

Criminal liability in the field of land and investment other than by individuals can also be done by the Legal Body for example: Company, Company, Collection, Foundation or Cooperative. Corporations in the form of legal entity if indicated as subject of criminal law hence its formulation is wider if compared with corporation definition according to civil law. According to criminal law, the definition of corporation may take the form of a legal entity or non-legal entity. In relation to corporate liability, there are three models of accountability related to a crime committed by a corporation:

1. Management as the perpetrators and administrators also responsible.

2. Corporations as responsible perpetrators and administrators.

3. Corporations as perpetrators and also those responsible.

Based on the above, criminal liability or criminal law, consisting of three conditions, namely:

1. The responsible or accountable ability of the perpetrator.

2. The existence of unlawful acts that is the psychic attitude of the perpetrator associated with the behavior that is: Deliberate and unintentional or unhealthy attitude - the heart or negligent.

3. There is no justification or excuse that eliminates criminal responsibility for the offender ${ }^{14}$.

\section{3) Criminal Sanctions and Penalties Against Criminal Actors in the aspect of Climate Change}

The term Criminal law contains several meanings, or rather it is said that the criminal law can be viewed from several angles, namely: First from the point of criminal law in a subjective sense and from the point of criminal law in an objective sense. Criminal law in the objective sense or called iuspoenale that is a number of regulations containing prohibitions or imperatives where the violation can be threatened by law. IusPoenale can be divided into material criminal and criminal law. The material criminal law contains rules on:

Nahak, S. (2017). Criminal law policy on land functions impacting climate change in Indonesian national law perspective. International Journal of Social Sciences and Humanities, 1(3), 28-39. https://doi.org/10.29332/ijssh.v1n3.50 
a. Penalties that can be punished with punishment (strafbaargeiten);

b. Who can be punished, or in other words set the responsibility for criminal law;

c. What punishment can be imposed on a person who commits an act contrary to law or also called penitent law ${ }^{15}$

Penal sanctions and criminal penalties in the field of Climate Change Law have not been regulated in criminal provisions even though the Environmental Protection and Management Act on Climate Change has been regulated, so that when there is crime in the field of climate change, law enforcers still use the provisions in article 97 to article 120 Act no. 32 of 2009 on the protection and pengelolahan environment. The contents of criminal provisions in general outline people who deliberately and/or neglect to commit environmental crime, thus resulting in harm to humans and the environment. In the event that a person commits a violation of environmental provisions, such as circulating genetic engineering, generates B3 waste without carrying out liability, the criminal provisions are not only individual persons, but the licensors or in this case the environmental licensing officer, as well as the person in charge business.

More on environmental law enforcement as has happened in some cases, whenever a crime of environmental crime occurs, the most closely related to corporate crime. Corporations in this case may also be subject to environmental criminal provisions if in their activities allegedly have undertaken destructive, reducing, or altering activities within specified limits. If a corporation turns out to have committed a serious environmental crime then it should be noted that the rules of the environmental criminal law provisions themselves, but if the corporate action is more directed to other responsibilities then civil law instruments and administrative legal instruments may be used.

As for who is responsible in the crime of climate change field conducted by the corporation, it can be seen in article 55 of the Criminal Code of the first book that gives threat to the people who do (pleger), who enjoined (doenpleger), who also did (medepleger), And the persuade (uitlokker). Thus, if proceeding in article 55 of the Criminal Code (Penal Code) then the sanction can be started from the leader of a corporation, then the ordering of the activity until the people who do the activities that essentially do environmental crimes.

It should be understood that the provisions of criminal law instruments are strongly influenced by the ability of accountability and the element of error, so that in strafbaarfeit refers to the behavior of persons formulated in the law, which is against the law, and therefore should be criminalized. In the opinion of pompe and vost experts who embrace a lawless understanding synonymous with "in strijd met het recht" or arguably contrary to law. Contrary to the law is not only judged as matters contrary to the law but with the decency.

Furthermore, if you see the meaning of strafbaarfeit then it can be questioned what its relationship with environmental law. Answering the question regarding the relationship between strafbaarfeit and environmental law then in essence according to HerminHadiatiKoeswadji, there are two important elements, namely:

That feit in strafbaarfeit means hendeling, behavior, behavior that is in the real world that can be perceived by the five senses. That the meaning of strafbaarfeit is related to the fault of the person who caused the behavior, ie, to be in the depth of the heart or not to be sensed with the senses.

These two important elements are easy to prove because when viewed from the first element it is clear that the form of forest destruction, water pollution, and all actions that can be considered an environmental crime. While concerning the second element, the error of a person associated with his inner mood is that the person knows and feels the action is in contradiction with his inner self.

In the case of a criminal act committed by a corporation, in addition to imprisonment and a fine to its commission, the penalty that may be imposed on the corporation shall be a fine of 3 (three) times of the fine as referred to above. In addition to the criminal penalty as 
referred to above, the corporation may be subject to additional criminal sanctions in the form of: revocation of business license and / or revocation of legal entity status.

It should be understood that in the provisions of the criminal law instrument is strongly influenced by the ability of accountability and the element of error, so in strafbaarfeit refers to the behavior of people who are formulated in the law, which is against the law, and therefore should be punished. In the opinion of pompe and vost experts who embrace a lawless understanding synonymous with "in strijd met het recht" or arguably contrary to law. Contrary to the law is not only judged as matters contrary to the law but with the decency.

Criminal penalties should not be used to punish non-harmful acts but specifically the formulation of criminal law sanctions in the related field is ultimumremedium where expressly its use must be considered from the economic and financial aspects to advance the prosperity of criminal victims in the field of climate change.

The Criminal Theory used to analyze this discussion is the Combined Theory of Penance by Vos described in Bambang Poernomo, explaining that in the combined theory there are 3 (three) streams, namely:

1. Combined theories that emphasize revenge, but with the intention of the criminal nature of retaliation to protect the rule of law. Zeven Bergen states in this respect the nature of the criminal is retaliation, but for the purpose of protecting lawful order, to respect to law and government. Thus in essence the penalty is only an "UltimumRemedium" (in the end that can heal that a last resort may be used if there is no other way);

2. Combined theory that emphasizes the protection of public order. This theory is embraced by Simons who uses the notion that public prevention lies in the horror of crime, repair and destruction, and then in absolute terms the penalty must be adapted to the legal consciousness of the members of society;

3. Combined theory that emphasizes equality of retaliation and protection of public interest. This follower is De Pinto, whom Vos explained that because in general a criminal must satisfy the society the criminal law must be structured in such a way as a fair criminal law, with the idea of retaliation that can not be neglected negatively or positively ${ }^{17}$.

The character of criminal law that proves certainty is the validity of the principle of legality, the retroactive principle, so that based on the two principles, it is assured that there is a certainty of criminal law which is the ultimate auxiliary tool (UltimumRemedium). The punishment system is based on the First Book of Chapter II Punishments, Article 10 of the Criminal Code determines: "Penalties are, principal punishments, death penalty, imprisonment, imprisonment, fine. Additional penalties: revocation of certain rights, the appropriation of certain goods, the announcement of a judge's verdict.

\subsection{Criminal sanctions regulation of land conversion that impact climate change in national perspective}

Criminal sanctions arrangements Criminal damages to the environment and spatial arrangements are set forth in the Environmental Protection and Management Act, the Spatial Planning Act, but the Special Criminal Climate Change Arrangement has not been regulated, so according to the author's opinion, it must be regulated in a separate law. Even if it is not regulated in a separate law, it should be formulated in the Environmental Protection and Management Act or Spatial Planning Act, by adding the formulation of the provisions of the Criminal Code with the plan:

"Anyone who deliberately oppose the law is to take action which causes the climate change either as a direct or indirect result of human activity resulting in a change in the composition of the atmosphere globally and in addition, also changes in natural climate variability observed in comparable periods, Shall be subject to imprisonment of a minimum of 4 (four) years and a

Nahak, S. (2017). Criminal law policy on land functions impacting climate change in Indonesian national law perspective. International Journal of Social Sciences and Humanities, 1(3), 28-39. https://doi.org/10.29332/ijssh.v1n3.50 
maximum of 15 (fifteen) years and a fine of at least Rp 4.000.000,00 (four billion rupiahs) and a maximum of Rp 15,000,000.00 (fifteen billion rupiah )

The theory used to analyze the void of legal norms is to use the theory of lawfulness according to J.J.H. Brugink writes that: there are 3 (three) kinds of law enforcement, namely:

1. The normative or formal validity of the rule of law, namely jiika a rule is part of a system of certain legal rules in which there are rules of law are pointing at each other. Thus the rule of law system comprises a whole hierarchy of specific legal rules based on general law rules, lower specific legal rules derived from higher general law rules;

2. The factual or empirical validity of the rule of law, ie, the effectiveness of factual or effective if the citizens, for each rule of law apply, comply with the rule of law. This situation can be assessed from empirical research, and the rule of law is said to have a factual validity if the rule is in fact genuinely obeyed by citizens and by authorized officials sincerely applied and enforced. Thus the rule of law is said to be effective, because it successfully influences the behavior of citizens and officials. The fact that there is factual validity can be examined in sociology of law by means of methods prevalent in the social sciences. In the perspective of the sociology of law, the law appears as das sollen and sein, convinced of the sociological reality (actual social behavior in reality of the real society) which refers to normative imperatives (rules);

3. The evaluative validity of the rule of law, namely the rule of law based on its content is considered to be valuable. In determining the state of evaluative validity, it can be approached empirically and by conviction ${ }^{18}$.

\section{Conclusion}

Examples of actions in terms of criminal aspects of Climate Change for example: the use of laserdisc to break the clouds, excessive use of greenhouses, the transition of land functions from rice fields into homes, shop houses, transfer of land from protected forests into hotels, factories, marine and lake reclamation and Other acts in the form of systematic deeds in the name of development. Criminal liability is based on error theory (liability based on fault or culpability). Criminal and criminal penalties under Criminal provisions in the Environmental Protection and Management Act. Penalty system based on Article 10 of the Criminal Code with a mechanism of law based on the Criminal Procedure Code.

The regulation of criminal sanctions is formulated in the Criminal provisions that any person who intentionally violates the law by taking actions that cause climate change either directly or indirectly causes a change in the composition of the atmosphere globally but, in addition, causes changes in natural climate variability observed over a period of time Compared, punished with imprisonment for a minimum ....years and longest ..... years and fines of at least $\mathrm{Rp}$... and at most $\mathrm{Rp}$........

\section{Suggestions}

1) Because of the crime of climate change in the form of an act that endangers the safety of mankind, it should be nationally necessary to justify the type of criminal act in the aspect of climate change explicitly, so that after known can definitely be handled with the regulation of criminal law.

2) Whereas the regulation of criminal sanctions on climate change, although it has been regulated in terms of climate change in the Law on Environmental Protection and Management, but in the Criminal provisions on Climate Change has not been regulated so that in the future the amendments to the Law on Environmental Protection and Management need to be regulated by the formulation of Criminal provisions "Climate Change" with the appropriate formula. 


\section{Acknowledgement}

My deep and sincere gratitude were presented to God for having granted me the ability and the opportunity to complete this paper. As well as, I have much appreciated to my friends for their support, suggestion, contribution in finishing this research. I would like thanking Suryasa that has given me a good advisement. Last but not least, I dedicated my dreadful thank to my friend who those as editor in SS of International Journal.

Nahak, S. (2017). Criminal law policy on land functions impacting climate change in Indonesian national law perspective. International Journal of Social Sciences and Humanities, 1(3), 28-39. 


\section{References}

1. Adetunji, A. T., Adetunji, A. V., Adeleke, E. O., \& Madubuike, S. C. (2017). Deregulation: The Effect of Market-led Approach to Nigerian Universities Management. International Journal of Social Sciences and Humanities (IJSSH), 1(1), 1-8. View in (Google Scholar)

2. Angelidis, J. P., \& Ibrahim, N. A. (1993). Social demand and corporate supply: a corporate social responsibility model. Review of Business, 15(1), 7. View in (Scopus), (Google Scholar)

3. Billaiya, R., Malaiya, S., \& Parihar, K. S. (2017). Impact of Socio Economic Trends on Students in Quality Education System. International Journal of Social Sciences and Humanities (IJSSH), 1(1), 16-20. View in (Google Scholar)

4. Bruggink, J. J. H. (1996). Refleksi tentang Hukum, terjemahan Bernard Arief Sidharta. Bandung: Citra Aditya Bakti. View in (Scopus), (Google Scholar)

5. Calvin A. Toala Arcentalis, Reinaldo Guillen Gordin, Antonia Vazquez Perez, Alfredo Zambrano Rodriguez, Climatization, Energy Efficiency and Environmental Protection, IRJEIS, International Research Journal of Engineering IT \& Scientific Research, Vol. 3 Issue, 2. March 2017, ISSN: 2454.2261, Impact FActor: 5.211, Publish by International Journal of College and University. View in (Thomson Reuters) (Google Scholar)

6. Cedeño, M. L. D., Arteaga, M. G. D., Pérez, A. V., \& Arteaga, M. L. D. (2017). Regulatory Framework for Renewable Energy Sources in Ecuador Case Study Province of Manabí. International Journal of Social Sciences and Humanities (IJSSH), 1(2), 29-42. View in (Google Scholar)

7. Edelman, L. B., \& Suchman, M. C. (1997). The legal environments of organizations. Annual review of sociology, 23(1), 479-515. View in (Scopus), (Google Scholar)

8. Faure, M., \& Wibisana, A. (Eds.). (2013). Regulating disasters, climate change and environmental harm. Edward Elgar Publishing. View in (Google Scholar)

9. Gámez, M. R., Pérez, A. V., Será, A. S., \& Ronquillo, Z. M. (2017). Renewable Energy Sources and Local Development. International Journal of Social Sciences and Humanities (IJSSH), 1(2), 1019. View in (Google Scholar)

10.Ghosh, C. (2017). A Study on-Evaluating Marketing Strategies Adopted by Home Appliance for Economic Development in India. International Journal of Social Sciences and Humanities (IJSSH), 1(1), 9-15. View in (Google Scholar)

11. Habermas, J. (1996). Between facts and norms: Contributions to a discourse theory of law and democracy. Mit Press. View in (Google Scholar)

12. Hall, J. (1946). General Principle* of. Criminal Law, 42. View in (Scopus), (Google Scholar)

13. Handayani, E. P., Nurjaya, I. N., Naviana, I., \& Djatmike, P. (2016). The Policy of Crime on the Resolution of Defamation Case Conducted by Citizen Journalist in Human Right Perspective. JL Pol'y \& Globalization, 56, 54. View in (Google Scholar)

14. Kelsen, H. (1967). Pure theory of law. Univ of California Press. View in (Scopus), (Google Scholar)

15. Khairandy, R. (2009). Corruption in State Enterprise Especially Corporation: A Study of the Meaning of State Property Separated from the State Finance. Jurnal Hukum IUS QUIA IUSTUM, 16(1). View in (Google Scholar)

16. Kriekhoff, V. J. (2001). Mediasi (Tinjauan Dari Segi Antropologi Hukum). Antropologi. View in (Google Scholar)

17. Law Number 8 Year 1981 regarding the Criminal Procedure Code. View in (Scopus), (Google Scholar)

18. Moeljatno, Principles of Criminal Law of Bandung: Alumni, 1987. View in (Google Scholar) 
19. Paul Scholten, Structure of Legal Science, translated by B. Arief Sidharta, in the Bandung Legal Basics series: No Publication No. 1 Laboratory Faculty of Law Catholic University of Parahyangan, 1997. View in (Scopus), (Google Scholar)

20.Peter Mahmud Marzuki, Penelitian Hukum, Jakarta: Kencana Prenada Media Group, 2006. View in (Scopus), (Google Scholar)

21.Poernomo, B., Richmond, W. C., Wicaksono, A. H., Béguin, P., Benimeli, D., ... \& Farag, S. (2001). Resistivity behind casing. Oilfield Review, 13(1), 2-25.View in (Scopus), (Google Scholar)

22.Simon Nahak, Lecture Material Law Criminal Procedure, Law Studies Program, Textbook, Denpasar: Warmadewa University, 2015.

23.Simon, R. I., \& Shuman, D. W. (2007). Clinical manual of psychiatry and law. American Psychiatric Pub. View in (Scopus), (Google Scholar)

24.Sunarso, S. (2009). Hukum informasi dan transaksi elektronik: studi kasus, Prita Mulyasari. Rineka Cipta. View in (Google Scholar)

25.www.Penataanruang.com/dispute-investigation-and-criminal-html, accessed March 12, 2014.

\section{Biography of Author}

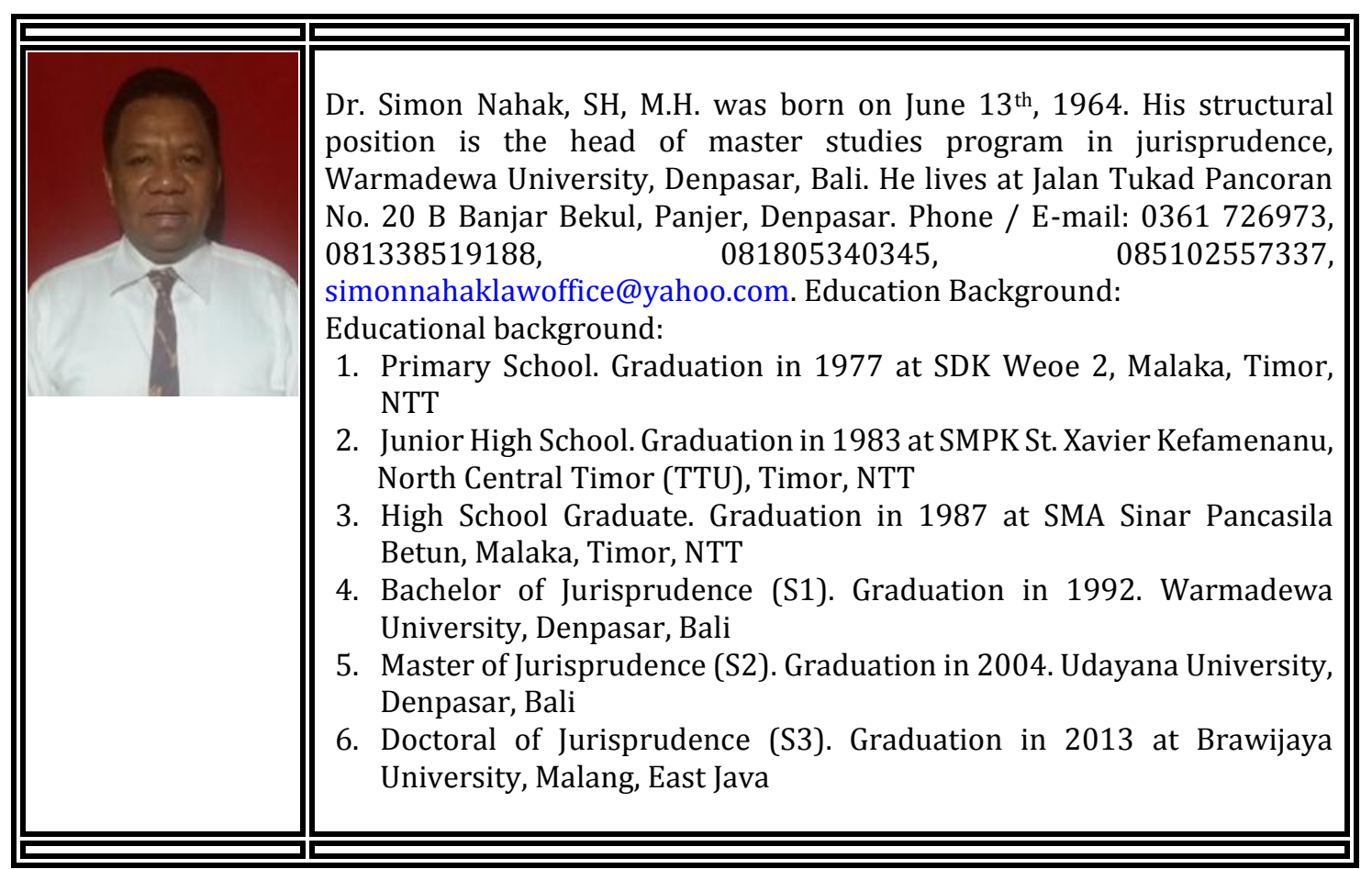

Nahak, S. (2017). Criminal law policy on land functions impacting climate change in Indonesian national law perspective. International Journal of Social Sciences and Humanities, 1(3), 28-39. https://doi.org/10.29332/ijssh.v1n3.50 